\title{
Purification and regulation of aspartate transcarbamylase from germinated mung bean (Vigna radiata) seedlings
}

\author{
P. V. PRASAD* and N. APPAJI RAO \\ Department of Biochemistry, Indian Institute of Science, Bangalore 560012, India \\ * Present Address: Division of Biochemistry, Scripps Clinic and Research Foundation, \\ 10666, North Torrey Pines Road, La Jolla, California 92037, USA \\ MS received 29 November 1983; revised 13 April 1984
}

\begin{abstract}
Aspartate transcarbamylase (EC 2.1.3.2) was purified to homogeniety from germinated mung bean seedlings by treatment with carbamyl phosphate. The purified enzyme was a hexamer with a subunit molecular weight of 20,600. The enzyme exhibited multiple activity bands on Polyacrylamide gel electrophoresis, which could be altered by treatment with carbamyl phosphate or UMP indicating that the enzyme was probably undergoing reversible association or dissociation in the presence of these effectors. The carbamyl phosphate stabilized enzyme did not exhibit positive homotropic interactions with carbamyl phosphate and hysteresis. The enzyme which had not been exposed to carbamyl phosphate showed a decrease in specific activity with a change in the concentration of both carbamyl phosphate and protein. The carbamyl phosphate saturation and U M P inhibition patterns were complex with a maximum and a plateau region. The partially purified enzyme also exhibited hysteresis and the hysteretic response, a function of protein concentration, was abolished by preincubation with carbamyl phosphate and enhanced by preincubation with UMP. All these observations are compatible with a postulation that the enzyme activity may be regulated by slow reversible association-dissociation dependent on the interaction with allosteric ligands.
\end{abstract}

Keywords. Aspartate transcarbamylase; mung bean; purification; regulation; hysteresis; association-dissociation.

\section{Introduction}

Aspartate transcarbamylase (EC 2.1.3.2) catalyzes the carbamylation of L-aspartate to $\mathrm{N}$-carbamyl L-aspartate by carbamyl phsophate with the release of orthophosphate $\left(P_{i}\right)$. This is the first committed step in pyrimidine biosynthesis in microorganisms and plants (Bethell and Jones, 1969; Neumann and Jones, 1964). Although extensive studies were conducted with the enzyme from Escherichia coli, relatively little information is available on the enzyme from plant sources. The enzyme from wheatgerm (Yon, 1981) and mung bean seedlings (Achar et al., 1974; Rao et al., 1979) has been purified to homogeneity. Earlier methods of purification of the enzyme from mung bean yielded preparations which were unstable and hence only a few kinetic and regulatory properties were studied (Savithri et al., 1978a, b). It was therefore necessary to standardize a purification procedure which yielded a stable enzyme preparation. This

Abbreviations used: $P_{i}$, Orthophosphate; DEAE, diethylaminoethyl; GdmCl, guanidinium chloride, Buffer A, $50 \mathrm{mM}$ sodium acetate-acetic acid buffer, $\mathrm{pH} 4.7$ containing $6 \mathrm{M} \mathrm{GdmCl} ; M_{r}$, molecular weight; Tris, Tris(hydroxymethyl) aminomethane; SDS, sodium dodecyl sulphate; PALA, N-phosphonoacetyl-L-aspartate. 
paper describes a modified procedure for the purification of the enzyme and a probable mechanism for the regulation of the enzyme activity by slow reversible association-dissociation.

\section{Materials and methods}

\section{Materials}

All the chemicals were obtained from Sigma Chemical Co., St. Louis, Missouri, USA, except diethyl aminoethyl-(DEAE)-cellulose (DE-52) which was obtained from Whatman Ltd., Maidstone, Kent, UK. Mung bean seeds were purchased from the local market.

\section{Methods}

Carbamyl phosphate was purified by the method of Gerhart and Pardee (1962). $\omega$ Aminohexyl-Sepharose was prepared by coupling 1,6-diaminohexane to cyanogens bromide activated Sepharose 4B (March et al., 1974). Protein was estimated by the method of Lowry et al. (1951) using bovine serum albumin as the standard. Subunit molecular weight $\left(M_{r}\right)$ of the enzyme was determined by gel filtration on Sepharose 6B in $6 \mathrm{M}$ guanidinium chloride $(\mathrm{GdmCl})$ (Mann and Fish, 1972). Polyacrylamide gel electrophoresis (PAGE) was conducted according to Davis (1964).

\section{Estimation of the enzyme activity}

The standard assay mixture $(1 \mathrm{ml})$ contained $0 \cdot 1 \mathrm{M}$ Tris(hydroxymethyl)aminomethane (Tris)-acetate buffer, $\mathrm{pH} 8 \cdot 0$, carbamyl phosphate $(2.5 \mathrm{mM})$, Laspartate $(10 \mathrm{mM})$ was neutralised to $\mathrm{pH} 8.0$ with $\mathrm{NaOH}$ and an appropriate amount of the enzyme. The reaction was started by the addition of L-aspartate unless otherwise indicated. After incubation for $20 \mathrm{~min}$ at $25^{\circ} \mathrm{C}$, the reaction was terminated by the addition of $0.05 \mathrm{ml}$ of $20 \%$ perchloric acid. The amount of N-carbamyl L-aspartate formed was estimated (Prescott and Jones, 1969). When partially purified enzyme preparations were used, the denatured protein after the addition of perchloric acid was removed by centrifugation at $1,000 \mathrm{~g}$ for $10 \mathrm{~min}$ before the addition of the reagents to develop the colour.

\section{Results}

Isolation of aspartate transcarbamylase from germinated mung bean seedlings

All the operations were carried out at $0-4^{\circ} \mathrm{C}$. All centrifugations were performed in a Sorvall RC 5B refrigerated centrifuge at $10,000 \mathrm{~g}$ for the time intervals indicated.

\section{Crude extract}

Mung bean $(2.5 \mathrm{~kg})$ seedlings germinated for $48 \mathrm{~h}$ were thoroughly washed with distilled water, chilled and blended in 4 batches with $200 \mathrm{ml}$ each of $0 \cdot 1 \mathrm{M}$ Tris-acetate buffer, $\mathrm{pH} 8 \cdot 0$. The homogenate was passed through two layers of cheese-cloth and the filtrate was centrifuged for $30 \mathrm{~min}$. The resulting supernatant was designated as crude 
Table 1. Purification of aspartate transcarbamylase from mung bean (Vigna radiata) seedlings.

\begin{tabular}{lccccc}
\hline Fraction & $\begin{array}{c}\text { Total } \\
\text { protein } \\
(\mathrm{mg})\end{array}$ & $\begin{array}{c}\text { Total } \\
\text { activity } \\
\left(\text { Units* }^{*}\right)\end{array}$ & $\begin{array}{c}\text { Specific } \\
\text { activity } \\
(\text { Units/mg) }\end{array}$ & $\begin{array}{c}\text { Yield } \\
\text { per cent }\end{array}$ & $\begin{array}{c}\text { Fold } \\
\text { purification }\end{array}$ \\
\hline Crude extract & 24752 & 40.8 & 0.00165 & 100 & - \\
$\begin{array}{l}\text { MnSO }_{4} \text { supernatant } \\
\begin{array}{c}\text { First }\left(\mathrm{NH}_{4}\right)_{2} \mathrm{SO}_{4} \\
\text { fractionation }\end{array}\end{array}$ & 22400 & 40.6 & 0.00181 & 100 & 1 \\
$\begin{array}{c}\text { DEAE-Cellulose } \\
\text { eluate }\end{array}$ & 6103 & $25 \cdot 4$ & 0.0042 & 62 & 3 \\
$\begin{array}{c}\text { Second }\left(\mathrm{NH}_{4}\right)_{2} \mathrm{SO}_{4} \\
\text { fractionation }\end{array}$ & 2102 & $22 \cdot 7$ & 0.0105 & 56 & 6 \\
$\begin{array}{c}\text { AH-Sepharose } \\
\text { fractions }\end{array}$ & 819 & 12.6 & 0.0154 & 31 & 9 \\
\hline
\end{tabular}

$* \mu$ mol N-carbamyl-L-aspartate formed per min at $\mathrm{pH} 8.0$ and $25^{\circ} \mathrm{C}$.

extract (1820 ml, table 1). To the crude extract, $\mathrm{MnSO}_{4}$ was added to a concentration of $10 \mathrm{mM}$ and stirred for $30 \mathrm{~min}$. The precipitated nucleoproteins were removed by centrifugation for $30 \mathrm{~min}\left(1750 \mathrm{ml}\right.$, table 1). To the $\mathrm{MnSO}_{4}$ supernatant, solid $\left(\mathrm{NH}_{4}\right)_{2} \mathrm{SO}_{4}$ was added to $45 \%$ saturation and the supernatant fraction was raised to $60 \%$ saturation by a further addition of solid $\left(\mathrm{NH}_{4}\right)_{2} \mathrm{SO}_{4}$. The precipitate obtained was dissolved in $001 \mathrm{M}$ Tris-acetate buffer, $\mathrm{pH} 8.0$ and desalted in 2 batches on a column $(3.5 \times 50 \mathrm{~cm})$ of Sephadex G-25 previously equilibrated with the same buffer $(193 \mathrm{ml}$, table 1). The desalted enzyme was loaded on to a DEAE-cellulose column $(2 \times 60 \mathrm{~cm})$ equilibrated previously with $0.01 \mathrm{M}$ Tris-acetate buffer, $\mathrm{pH} 8 \cdot 0$. The column was washed with $500 \mathrm{ml}$ of $0.05 \mathrm{M} \mathrm{KCl}$ solution and the enzyme was eluted with $0 \cdot 2 \mathrm{M} \mathrm{KCl}$ solution (198 $\mathrm{ml}$, table 1). The enzyme was precipitated at $45-60 \%$ saturation and dissolved in $0.01 \mathrm{M}$ potassium phosphate buffer, $\mathrm{pH} 7.6$ and desalted on a column (2 $\times 50 \mathrm{~cm})$ of Sephadex G-25 in the same buffer. The desalted enzyme $(15 \mathrm{ml}$, table 1$)$ was passed through an $\omega$-aminohexyl-Sepharose column $(1 \times 25 \mathrm{~cm})$ equilibrated with $10 \mathrm{mM}$ potassium phosphate buffer, $\mathrm{pH} 7 \cdot 6$ at a flow rate of $10 \mathrm{ml} / \mathrm{h}$. The column was washed with $150 \mathrm{ml}$ of the equilibrating buffer followed by $150 \mathrm{ml}$ of the same buffer containing $0.05 \mathrm{M} \mathrm{KCl}$. The enzyme was eluted with a linear gradient $(100 \mathrm{ml})$ of $0 \cdot 05-0.5 \mathrm{M} \mathrm{KCl}$ in $10 \mathrm{mM}$ potassium phosphate buffer, $\mathrm{pH} 7 \cdot 6$. The eluting buffer also contained $2 \mathrm{mM}$ carbamyl phosphate to stabilize the enzyme. Fractions $(1 \mathrm{ml})$ were collected and the absorbance at $280 \mathrm{~nm}$ as well as enzyme activity of the fractions were determined. The fractions with high specific activity $(<6.0)$ were pooled and dialysed against $1 \mathrm{~L}$ of $10 \mathrm{mM}$ potassium phosphate buffer, $\mathrm{pH} 7 \cdot 6$ with $3-4$ changes. The dialysed enzyme ( $8 \mathrm{ml}$, table 1 ) was centrifuged at $15,000 \mathrm{~g}$ for $10 \mathrm{~min}$ and stored frozen at $-40^{\circ} \mathrm{C}$ in $1 \mathrm{ml}$ aliquots.

The enzyme obtained by this method had a specific activity of $\sim 6.0$ which was the highest reported so far for this enzyme from mung bean seedlings (Ong and Jackson, 1972; Achar et al., 1974; Rao et al., 1979). The results of a typical purification procedure are shown in table 1 . The recovery of the enzyme was about $26 \%$ with 3600 fold purification. 


\section{Preparation of the partially purified enzyme}

For some of the studies reported in this paper, a partially purified enzyme preparation was used. The second ammonium sulphate (table 1) precipitate was dissolved in $20 \mathrm{mM}$ Tris-acetate buffer, $\mathrm{pH} 8.0$ and desalted on a small column $(1.5 \times 15 \mathrm{~cm})$ of Sephadex G25 using the same buffer. The enzyme was used immediately. Control experiments showed that the enzyme retained complete activity for $2 \mathrm{~h}$ under these conditions. It was devoid of contaminating activities like carbamyl phosphate synthetase (EC 2.7.2.5), aspartokinase (EC 2.7.2.4), aspartate aminotransferase (EC 2.6.1.1) and phosphatase (EC 3.1.3.1). Its specific activity varied between $0 \cdot 01-0 \cdot 016$.

One unit of enzyme activity was defined as the amount of enzyme required to catalyze the formation of $1 \mu \mathrm{mol}$ of $\mathrm{N}$-carbamyl-L-aspartate per min at $25^{\circ} \mathrm{C}$ and $\mathrm{pH} 8 \cdot 0$. Specific activity was defined as units per $\mathrm{mg}$ of protein.

\section{Physicochemical properties of the enzyme}

Polyacrylamide gel electrophoresis: The purified enzyme showed multiple bands of enzyme activity (figure 1A) on PAGE and these corresponded with the protein bands (figure 1B). No additional protein bands were located on the enzyme when stained with Coomassie brilliant blue. The nature of these multiple bands is discussed later. As different staining procedures were used to locate enzyme activity and protein bands, the correspondence between the protein bands and activity bands was not very good.

Molecular weight of the enzyme: The $M_{r}$ of the enzyme was determined by gel filtration on Sephacryl S-200 (figure 1 D) to be 125,000 .

Molecular weight of the subunit: The enzyme could not be denatured completely by sodium dodecyl sulphate (SDS) even after extensive boiling in the presence of 2mercaptoethanol. Hence, the subunit $M_{r}$ of the enzyme was determined by gel filtration on sepharose $6 \mathrm{~B}$ in the presence of $6 \mathrm{M} \mathrm{GdmCl}$. The enzyme gave a single symmetrical peak and from a standard graph (figure 1C), the $M_{r}$ of the subunit was calculated to be 20,600 .

\section{Regulatory properties of the purified enzyme}

It was interesting to examine whether the enzyme isolated by this method retained its regulatory properties as some regulatory proteins are known to be desensitised during purification (Reddy et al., 1980).

\section{Carbamyl phosphate saturation of the enzyme}

The enzyme exhibited a hyperbolic saturation with carbamyl phosphate (figure 2 inset A). The hyperbolic nature of the carbamyl phosphate saturation was confirmed by a Hill plot (figure 2, inset B). When the data was fitted to the Hill equation by a least square analysis, a $n_{H}$ value of 1.1 and a $K_{0.5}$ value of $0.08 \mathrm{mM}$ were obtained. The hyperbolic nature of the saturation was further confirmed by Lineweaver-Burk and an Eadie plots (not shown) both of which were linear. This observation was not in agreement with the results of earlier workers (Rao et al., 1979; Savithri et al., 1978a, b), 


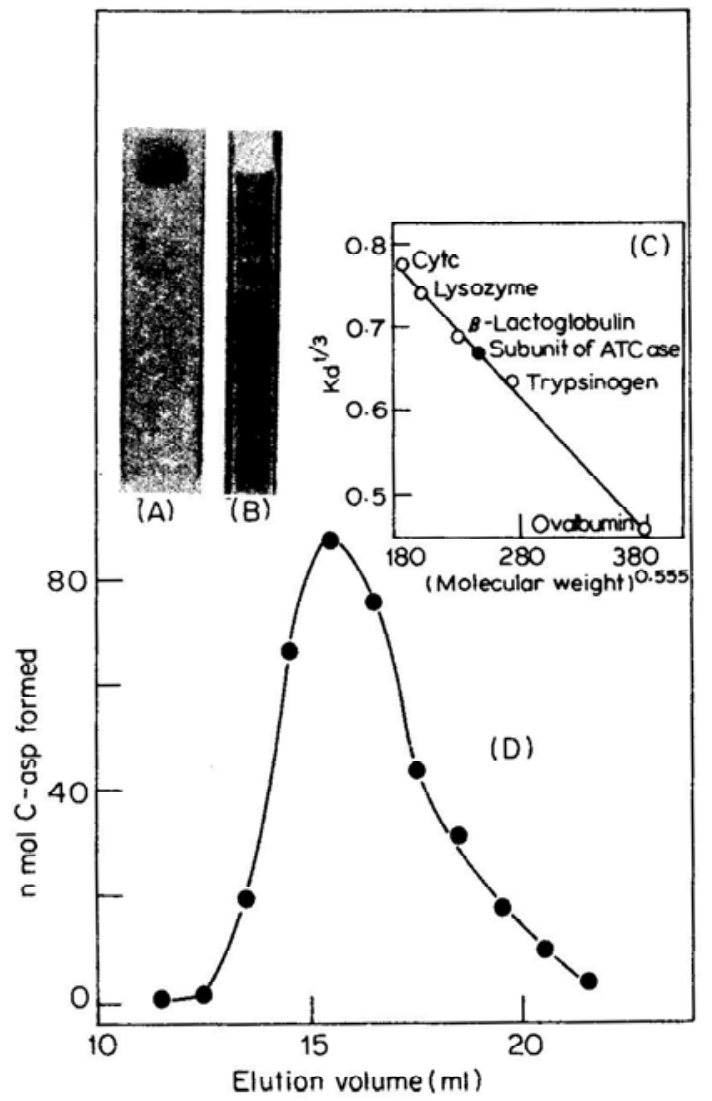

Figure 1. Molecular properties of mung bean ATCase. A and B. PAGE was conducted in Tri-glycine buffer, $\mathrm{pH} 8 \cdot 6$, at $4^{\circ} \mathrm{C}$. Bromophenol blue was used as the marker dye. The enzyme $(40 \mu \mathrm{g})$ was loaded on to $7 \cdot 5 \%$ gels and electrophoresis was conducted using a current of $2 \cdot 5 \mathrm{~mA} /$ tube. The gels were stained for protein using Coomasie brilliant blue R250 and destained with methanol:acetic acid:water (43:7:50). Activity staining was carried out according to a slightly modified procedure of Grayson and Yon (1978). Aspartate transcarbamylase activity was revealed as a white opalescent precipitate of calcium phosphate. C. A sepharose $6 \mathrm{~B}$ column $(1 \times 50 \mathrm{~cm})$ was equilibrated with $50 \mathrm{mM}$ sodium acetate-acetic acid buffer, $\mathrm{pH} 4.7$ containing $6 \mathrm{M} \mathrm{GdmCl}$ (Buffer A) and was calibrated by using ovalbumin $\left(M_{r}\right.$ 45,000), trypsinogen $\left(M_{r}\right.$ 24,000), lysozyme $\left(M_{r}\right.$ 14,300), cytochrome c $\left(M_{r}\right.$ 12,400) and $\beta$ lactoglobulin $\left(M_{r}\right.$ 18,400). Blue dextran was used to measure the void volume and methyl green to determine the internal volume of the column. As buffer A was very viscous, the volume of the fractions could not be measured accurately. Hence, the weight of the fractions was measured to calibrate the elution positions of markers and the enzyme. The enzyme (1 mg) or the standard proteins $(2 \mathrm{mg}$ each) were denatured in $6 \mathrm{M} \mathrm{GdmCl}$ and carboxymethylated at $\mathrm{pH} 8 \cdot 0$. The denatured protein solution $(0 \cdot 25 \mathrm{ml})$ was made upto $20 \%$ sucrose, $0.2 \%$ blue dextran and $0 \cdot 2 \%$ methyl green by adding the solid reagents. Fractions $(0.5 \mathrm{~g})$ were collected and the elution weights of protein and markers determined. D. A sephacryl S-200 column was equilibrated with $20 \mathrm{mM}$ Tris-acetate buffer, $\mathrm{pH} 80$ at $4^{\circ} \mathrm{C}$ and calibrated using cytochrome $\mathrm{c}\left(M_{r} 12,400\right)$, ovalbumin $\left(M_{r} 43,000\right)$, conalbumin $\left(M_{r} 68,000\right)$, yeast hexokinase $\left(M_{r}\right.$ 96,000) and bovine catalase $\left(M_{r} 232,000\right)$. The enzyme $(100 \mu \mathrm{g})$ was passed through this column separately and the activity in the fractions is shown in the figure. 


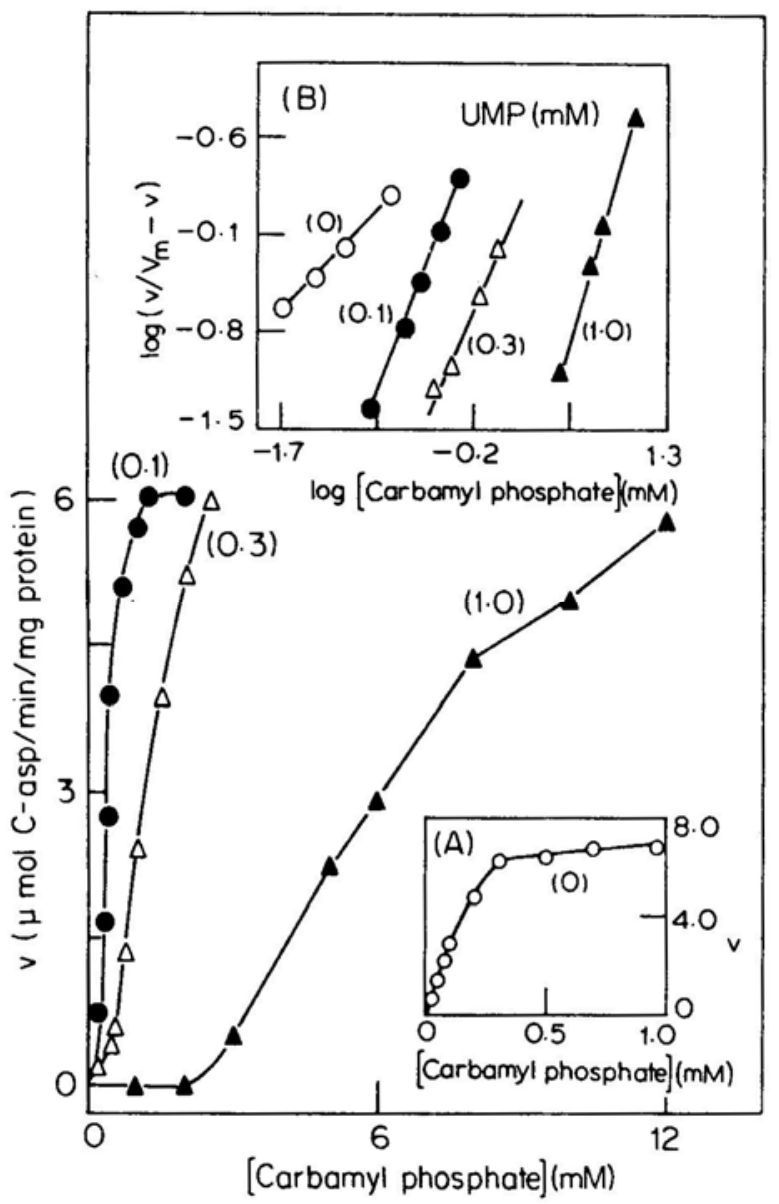

Figure 2. Saturation of the enzyme with carbamyl phosphate and the effect of UMP on this saturation.

The activity of the enzyme at concentrations of carbamyl phosphate in the range 0 to $1 \mathrm{mM}$ indicated in the inset $2 \mathrm{~A}$ was determined. The enzyme was preincubated with $0 \cdot 1(\mathbf{\bullet})$, or $0 \cdot 3(\Delta)$ or 1.0 ( $\mathbf{\Delta}) \mathrm{mM}$ UMP for $15 \mathrm{~min}$ and the enzyme activity assayed at carbamyl phosphate concentrations indicated in the figure inset $2 \mathrm{~B}$ Hill plot.

who showed that the enzyme exhibited homotropic co-operative interactions with carbamyl phosphate.

\section{Effect of UMP on carbamyl phosphate saturation}

UMP was earlier (Achar et al., 1974; Savithri et al., 1978a, b) shown to be an allosteric effector of the enzyme. It was therefore of interest to examine the effect of UMP on carbamyl phosphate saturation of the enzyme. The saturation of the enzyme with carbamyl phosphate in the presence of UMP was sigmoidal and the sigmoidicity increased with the increasing concentration of UMP (figure 2). This is more evident in (figure 2, inset B) where the carbamyl phosphate saturations are shown in the form of Hill plots. The 
$n_{H}$ and $K_{0.5}$ values of carbamyl phosphate saturation increased with increasing concentrations of UMP showing that UMP produced sigmoidicity in the carbamyl phosphate saturation. These results indicate that the purified enzyme retains its heterotropic interaction with UMP.

\section{Effect of UMP on the reaction velocity}

The inhibition of the enzyme by UMP followed a sigmoid pattern (figure 3 ) and a Hill plot analysis (figure 3 inset) gave a $n_{H}$ value of $2 \cdot 2$ and ${ }_{I} k_{0.5}$ value of $0.26 \mathrm{mM}$. This result indicated the heterotropic nature of the UMP inhibition and was consistent with the results reported earlier (Savithri et al., 1978b and Rao et al., 1979).

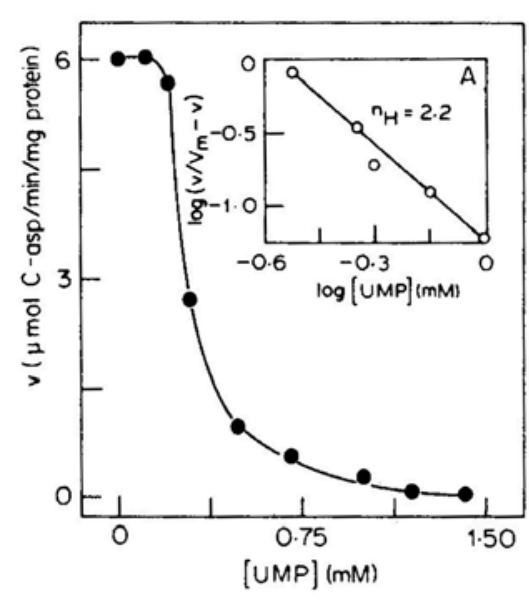

Figure 3. The inhibition of the enzyme activity by UMP. The enzyme $(1.4 \mu \mathrm{g})$ was preincubated with concentrations of UMP indicated in the figure and assayed at saturating concentrations of carbamyl phosphate $(1 \mathrm{mM})$ and $\mathrm{L}$-aspartate $(10 \mathrm{mM})$. Inset $A$. Hill plot.

\section{Hysteretic behaviour of the purified enzyme}

It was earlier shown that a partially purified enzyme exhibited hysteresis as evidenced by a lag phase in the time course of enzyme catalysed reaction (Rao et al., 1982). It was of interest to examine this property in the purified enzyme.

The progress curve of the enzyme catalysed reaction was linear when the reaction was started by the addition of the enzyme. Similar result was obtained when the enzyme was preincubated with $2.5 \mathrm{mM}$ carbamyl phosphate and the reaction started by the addition of $10 \mathrm{mM} \mathrm{L}$-aspartate. This result indicated the absence of hysteretic behaviour in the purified enzyme and was different from the results reported earlier with a partially purified enzyme preparation (Rao et al., 1982). However, upon preincubating the enzyme with $0 \cdot 1 \mathrm{mM}$ UMP and starting the reaction with carbamyl phosphate plus Laspartate a lag phase was observed in the time course of the reaction (figure 4).

When the enzyme was preincubated with $0 \cdot 1 \mathrm{mM}$ UMP for $30 \mathrm{~min}$ followed by a second preincubation with $2.5 \mathrm{mM}$ carbamyl phosphate for $15 \mathrm{~min}$ and the reaction started by the addition of $10 \mathrm{mM}$ L-aspartate the progress curve of the reaction did not show any lag phase. No lag phase was observed when the enzyme was not preincubated with UMP (figure 4, inset A). This indicated that the changes produced in the enzyme by UMP leading to a hysteretic response were reversed by carbamyl phosphate. This result 


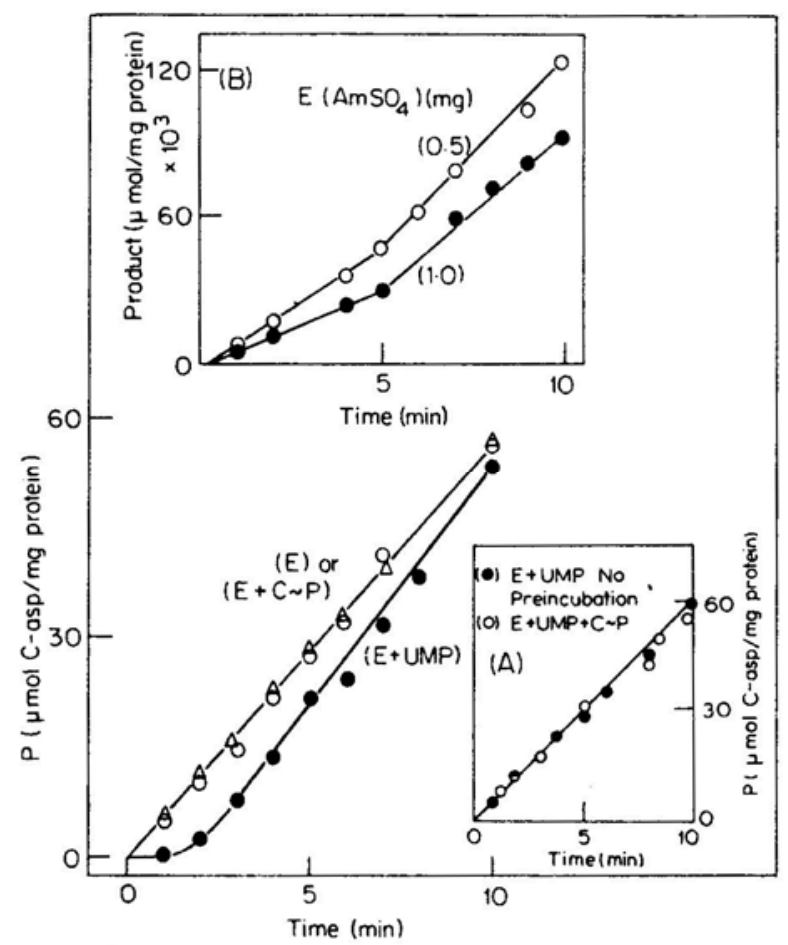

Figure 4. Progress of the reaction catalysed by the enzyme. The enzyme $(12 \cdot 2 \mu \mathrm{g}$, O $)$ or enzyme preincubated with carbamyl phosphate $(2 \cdot 5 \mathrm{mM}, \Delta)$ for $30 \mathrm{~min}$ or UMP $(0 \cdot 1 \mathrm{mM}, \bullet)$ for $30 \mathrm{~min}$ in a reaction mixture scaled up to $5 \mathrm{ml}$ and incubated at $25^{\circ} \mathrm{C}$. Aliquots $(0.5 \mathrm{ml})$ were withdrawn at time intervals indicated and assayed for enzyme activity. Inset $A$. The enzyme was preincubated with $0 \cdot 1 \mathrm{mM}$ UMP for $30 \mathrm{~min}$ followed by a second preincubation with carbamyl phosphate $(2.5 \mathrm{mM}, \mathbf{0})$ and the reaction was started by L-aspartate $(10 \mathrm{mM})$. In a control experiment the enzyme was not preincubated with UMP but the reaction mixtures contained $01 \mathrm{mM}$ UMP $(\mathrm{O})$. Inset $B$. The partially purified enzyme $(0 \cdot 5,1 \cdot 0 \mathrm{mg})$ was assayed for activity at different time points in the figure.

is in agreement with those reported for a partially purified enzyme (Rao et al., 1982). This phenomenon was further examined by preincubating the enzyme with $2 \mathrm{mM}$ carbamyl phosphate. The enzyme showed two bands on PAGE as revealed by both protein staining (figure 5A) and activity staining (figure 5B). On the other hand in the presence of $0.3 \mathrm{mM}$ UMP the enzyme migrated as a single band on PAGE as shown by both protein staining and activity staining (figure $5 \mathrm{C}$ and $\mathrm{D}$ ). These results indicated that the multiple forms of the enzyme observed on PAGE were interconvertible by carbamyl phosphate and UMP. To see whether these different forms were different in their molecular weights, the enzyme was subjected to gel filtration in the presence of these ligands as described below.

\section{Gel filtration behaviour of the enzyme of Sephacryl S-200}

The elution profile of the enzyme on Sephacryl S-200 in the presence of $2 \mathrm{mM}$ carbamyl phosphate was similar to that in the absence of any ligands. However, in the presence of 


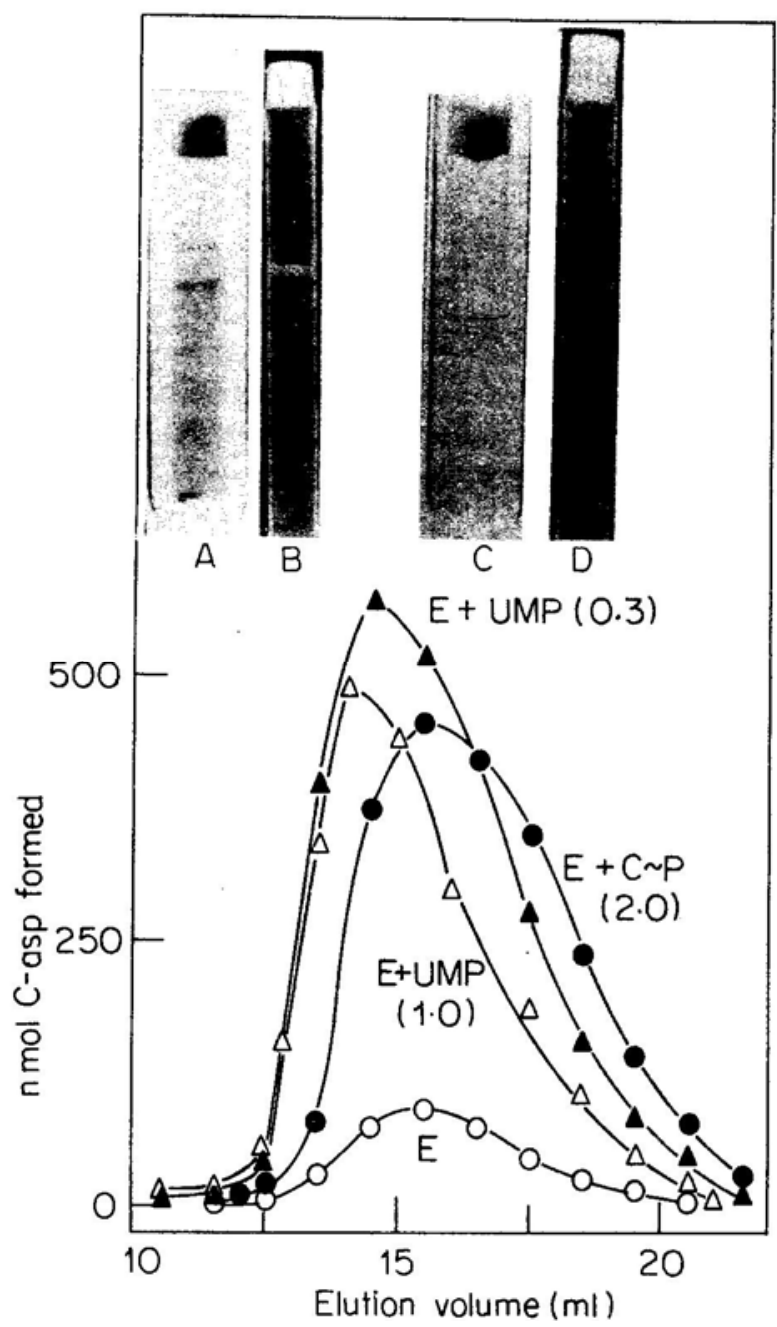

Figure 5. Alteration in the molecular weight of the enzyme in the presence of effectors. A Sephacryl column S-200 $(1 \times 35 \mathrm{~cm})$ was equilibrated with $20 \mathrm{mM}$ Tris-aeetate buffer, $\mathrm{pH} 8.0$ at $4^{\circ} \mathrm{C}$. When the gel filtration was conducted in the presence of ligands the equilibrating buffer contained the appropriate ligands. No ligand (O), UMP (0.3 mM, $\mathbf{\Delta})$, UMP (1 mM, $\Delta)$; carbamyl phosphate $(2 \mathrm{mM}, \bullet)$ Inset $A, B, C, D$. PAGE was conducted under conditions described in the legend for figure 1: When the electrophoresis of the enzyme $(40 \mu g)$ was conducted in the presence of carbamyl phosphate or UM P, the elctrode trey buffer contained carbamyl phosphate $(2 \mathrm{mM})$ or UMP $(0 \cdot 3 \mathrm{mM})$. Before electrophoresis the enzyme was preincubated with these legends for $10 \mathrm{~min}$. A. Protein staining. B. Activity staining for the enzyme preincubated with carbamyl phosphate. C. Protein staining. D. Activity staining for the enzyme preincubated with U M P.

$0 \cdot 3 \mathrm{mM}$ UMP the enzyme was eluted earlier. A greater shift in the elution position was observed when the U M P concentration was increased to $1 \mathrm{mM}$ (figure 5). The results of the gel filtration and electrophoretic behaviour of the enzyme in the presence of ligands 
show that the enzyme exists in an equilibrium between different molecular forms and the biospecific ligands can affect this equilibrium.

Possible consequences of changes in molecular forms on the regulatory properties of the enzyme

The kinetic properties of an aggregating enzyme depend on the protein concentration of the different molecular forms that have different kinetic properties (Frieden, 1971, 1981). Specific activity of the purified enzyme was examined over a protein concentration range of 2-20 $\mu \mathrm{g}$ per ml. However, there was no change in the specific activity $(6 \cdot 0)$ of the enzyme over this protein concentration range. It was not possible to increase the enzyme concentration beyond $20 \mu \mathrm{g}$ per $\mathrm{ml}$ as carbamyl phosphate consumption became rapid and was more than $10 \%$. Other experimental difficulties like the nonavailability of facilities to measure rapid reactions and the limited availability of the enzyme also precluded the study of the kinetic behaviour of the enzyme at high protein concentration. A slow association-dissociation system is not easily amenable for examination by simple physicochemical methods due to its inherent features. A theoretical paper of Kurganov et al. (1976) enables the use of kinetic approach to the examination of these systems even in partially purified preparations. The experimental procedures involve estimation of the specific activity of the enzyme, examination of the substrate and effector saturation profiles at different protein concentrations.

\section{Kinetic properties of a partially purified enzyme preparation}

The partially purified enzyme (second ammonium sulphate fraction, table 1) showed multiple protein bands on PAGE and activity staining gave multiple bands (data not shown) like the purified enzyme (figures 1A and B). In all the following experiments, precautions were taken to ensure that (a) the product formed was less than $10 \%$ of the substrate added by adjusting the reaction times and (b) the initial velocities were being measured.

\section{Effect of protein concentration on the specific activity of the enzyme}

The specific activity of the partially purified enzyme decreased with increasing protein concentration both at $1 \mathrm{mM}$ and $5 \mathrm{mM}$ concentrations of carbamyl phosphate when the reaction was started by the addition of the enzyme. Preincubation (30 min) with $2 \mathrm{mM}$ carbamyl phosphate resulted in a slight increase in the specific activity of the enzyme as compared with the buffer preincubated control, although a similar decrease in specific activity was observed with increasing protein concentration (data not given).

The partially purified enzyme solution $(1.5 \mathrm{ml})$ was made up to $2 \mathrm{mM}$ carbamyl phosphate by the addition of the solid reagent and was set aside for $8 \mathrm{~h}$. It was then dialysed against $1 \mathrm{~L}$ of $20 \mathrm{mM}$ Tris-acetate, buffer, pH8.0 with 4 changes of buffer. When the protein concentration dependence of the specific activity of this preparation was studied, it was observed that over a 10 -fold change in protein concentration, there was no change in the specific activity (table 2). The specific activity of this preparation was $0.027(\mu \mathrm{mol} / \mathrm{min} / \mathrm{mg}$ protein) as compared to the buffer treated control which had a specific activity of $0 \cdot 012$. 
Table 2. Dependence of specific activity on the concentration of a partially purified enzyme preparation treated with carbamyl phosphate.

\begin{tabular}{cc}
\hline $\begin{array}{c}\text { Protein } \\
(\mathrm{mg} / \mathrm{ml})\end{array}$ & $\begin{array}{c}\text { Specific Activity } \\
(\mu \mathrm{mol} / \mathrm{min} / \mathrm{mg})\end{array}$ \\
\hline 0.27 & 0.026 \\
0.54 & 0.027 \\
0.82 & 0.027 \\
1.10 & 0.026 \\
1.35 & 0.026 \\
1.63 & 0.027 \\
2.70 & 0.026 \\
\hline
\end{tabular}

The pattern of carbamyl phosphate saturation at different concentrations of the enzyme

When the reaction was started by the addition of the enzyme, the carbamyl phosphate saturations were complex with a maximum and a plateau region at all the protein concentrations (figure 6A). The velocity of the reaction at each concentration of carbamyl phosphate decreased with increasing protein concentration. On the other hand, when the enzyme was preincubated with various concentrations of carbamyl phosphate and the reaction started by the addition of L-aspartate, classical sigmoid

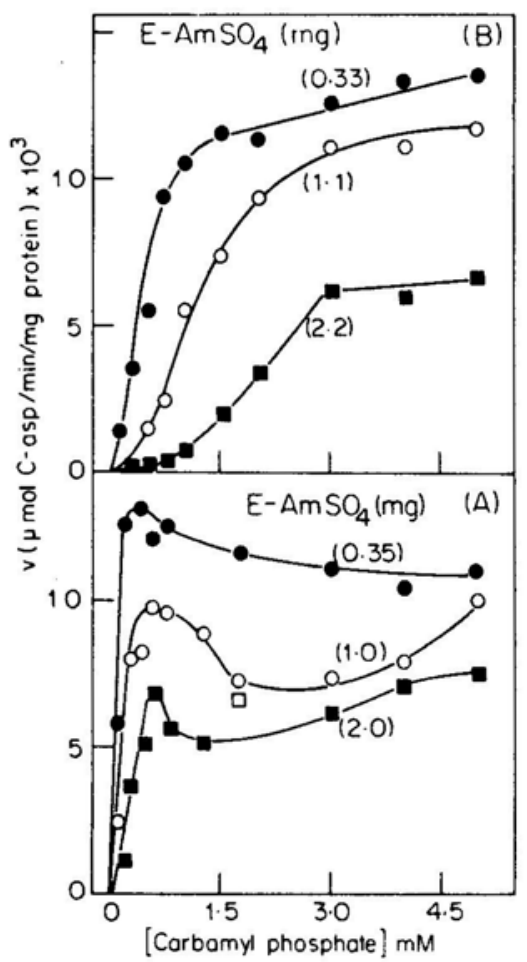

Figure 6. A. The saturation pattern of the partially purified enzyme with carbamyl phosphate.

The partially purified enzyme $(0 \cdot 35, \bullet, 1 \cdot 0, \mathrm{O}$, $2 \cdot 0$, 口) $\mathrm{mg}$ was added to reaction mixtures containing different concentrations of carbamyl phosphate indicated in the figure at saturating concentration of Laspartate. B. The partially purified enzyme $(0 \cdot 33, \mathbf{0}$; $1 \cdot 1,0 ; 2 \cdot 2$, 口) $\mathrm{mg}$ was preincubated for $30 \mathrm{~min}$ at $25^{\circ} \mathrm{C}$ and added to reaction mixtures containing concentrations of carbamyl phosphate indicated in the figure. 
patterns of substrate saturation were obtained (figure 6B). The sigmoidicity increased with increasing protein concentration $\left(n_{H}=1 \cdot 5-2 \cdot 8\right)$. The velocity of the reaction at all concentrations of carbamyl phosphate decreased with increasing protein concentration.

Effect of protein concentration on the UMP inhibition patterns of the partially purified enzyme

The UMP inhibition pattern of the enzyme at different protein concentrations was sigmoid as indicated by $n_{H}$ values greater than $2 \cdot 0$ when the reaction was started by the addition of the enzyme (figure 7A). On the other hand, when the enzyme was preincubated with varying concentrations of UMP and the reaction started by the

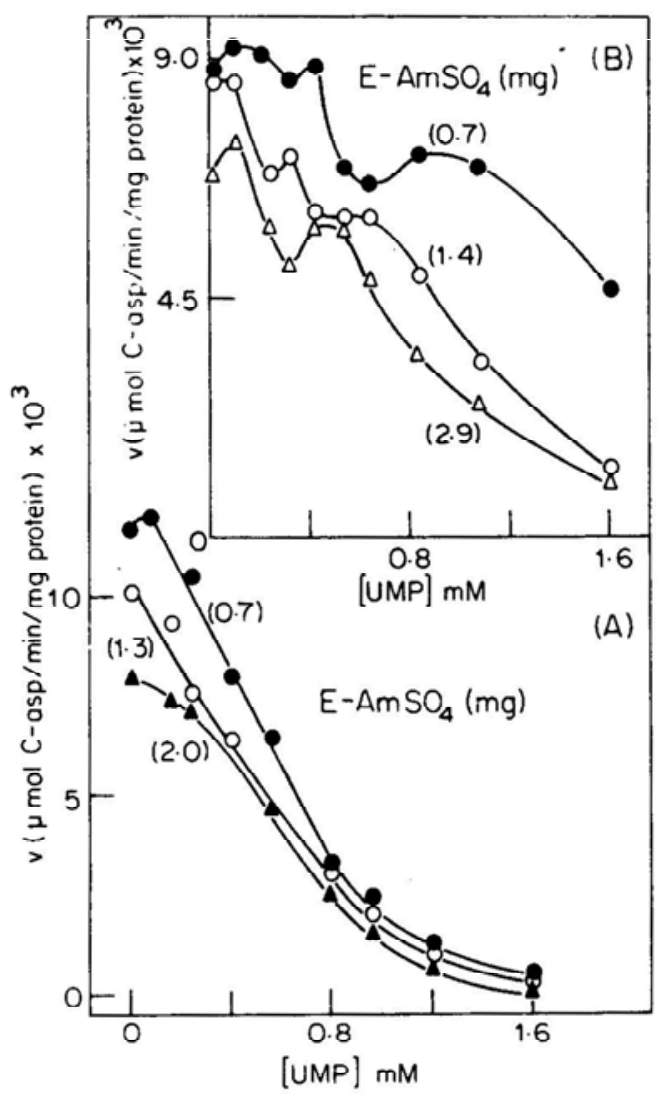

Figure 7. A. Inhibition of activity at increasing concentrations of UMP at different fixed concentrations of the partially purified enzyme.

The partially purified enzyme $(0 \cdot 7, \bullet, 1 \cdot 3,0 ; 2 \cdot 0, \mathbf{\Delta}) \mathrm{mg}$ was added to the reaction mixtures containing UMP at concentrations indicated in the figure. B. The partially purified enzyme $(0 \cdot 7, \bullet, 1 \cdot 4,0 ; 2 \cdot 9, \Delta) \mathrm{mg}$ was preincubated with varying concentrations of UMP indicated in the figure and assayed in the standard reaction mixtures containing the same concentrations of UMP. 
addition of carbamyl phosphate plus L-aspartate, the UMP inhibition patterns showed complex behaviour with intermediary plateaus (figure 7B). The velocity of the reaction at all concentrations of UMP decreased with increasing protein concentration.

\section{Time course of the reaction at different protein concentrations}

The partially purified enzyme exhibited hysteresis as indicated by a lag phase followed by a fast phase in the progress curve and this response was dependent on protein concentration (figure 4B).

\section{Discussion}

The enzyme obtained by the method of purification, described in table 1 was extremely stable, probably due to its interaction with carbamyl phosphate. Omission of this ligand in the eluting buffer resulted in a rapid loss of enzyme activity $\left(t_{1 / 2}=3 \mathrm{~h}\right)$. Exposure to $2 \mathrm{mM}$ carbamyl phosphate and subsequent dialysis resulted in an enzyme preparation which was stable for months when stored frozen at $-40^{\circ} \mathrm{C}$, and this effect was dependent on the ligand concentration. The interaction of the enzyme with $\mathrm{AH}$ Sepharose was probably through a combination of electrostatic and hydrophobic forces (Adler et al., 1975; Shaltiel and Er-El, 1973). The mechanism of stabilization by carbamyl phosphate may not be due to the tight binding of this ligand to the enzyme. This is suggested by the following observations: (i) The enzyme when incubated with L-aspartate in the absence of added carbamyl phosphate did not give rise to the products of the reaction. The amount of enzyme used in this study was sufficient to yield a detectable amount of product; (ii) extensive dialysis had no effect on the stability of the enzyme; (iii) an affinity matrix prepared by coupling the transition state analog, N-phosphonacetyl-L-aspartate (PALA) which has structural features of carbamyl phosphate and aspartate (Collins and Stark, 1971) to AH-Sepharose could also be used for the purification of the enzyme. The enzyme preparation thus obtained was stable even without the addition of carbamyl phosphate and had kinetic properties similar to the carbamyl phosphate-treated enzyme. It could be postulated that the exposure to this compound had stabilized the enzyme in a manner similar to that caused by carbamyl phosphate due to the presence of the structurally similar component in the transition state analogue.

Attempts at dissociating the enzyme into subunits by SDS were unsuccessful. Similar incomplete dissociation by SDS was observed for some hydrophobic proteins (Maddy, 1976; Koistinen, 1980; Graf et al., 1982). The determination of subunit $M_{r}$ by gel filtration in $6 \mathrm{M} \mathrm{GdmCl}$ indicated a hexameric structure for the mung bean aspartate transcarbamylose. Wheatgerm aspartate transcorbamylose was shown to be a trimer (Yon et al., 1982) which aggregated to higher $M_{r}$ forms in the presence of UMP (Grayson and Yon, 1978). The enzyme from B. subtilis (Brabson and Switzer, 1975) and the catalytic subunit of E. coli ATCase (Weber, 1968) are also trimeric. The enzymes associated with carbamyl phosphate metabolism appear to be mostly trimeric (Vickers, 1981). Thus a trimeric or a multiple of trimeric structure may be a general feature of transcarbamylases.

The purified and stabilized enzyme obtained in this study had properties different 
from the earlier preparations (Achar et al., 1974; Rao et al., 1979) in that it did not exhibit homotropic interactions with carbamyl phosphate and hysteresis. However, the enzyme retained the heterotopic interactions with UMP which also induced hysteresis.

The apparent differences between this enzyme preparation and those reported earlier (Achar et al., 1974; Rao et al., 1979) could be reconciled by assuming that treatment with carbamyl phosphate had altered the structure of the enzyme (figure 7B). This explanation finds support in the observation that the ammonium sulphate fraction treated with carbamyl phosphate behaves in an identical manner as that of the purified enzyme.

The multiple activity bands observed on PAGE (figures 1A and B) of the purified enzyme were inter-convertible by carbamyl phosphate (figures 5A and B) and UMP (figures 5Cand D) suggesting that they may not be isoenzymes. Similar multiple activity bands on PAGE which were inter-convertible by ligands were observed for some associating-dissociating systems like wheatgerm aspartate transcarbamylase (Grayson and Yon, 1978), bio-synthetic L-threonine dehydratase of E. coli (Kagan et al., 1975) and L-threonine deaminase of Rhodospirillum rubrum (Feldberg and Datta, 1971). The aggregation of mung bean aspartate transcarbamylase was further confirmed by gel filtration on Sephacryl S-200. UMP shifted the elution profiles of the enzyme towards higher $M_{r}$ region. Similar displacement of elution profiles in the presence of allosteric effectors was observed for some aggregating enzymes like isocitrate dehydrogenase (Kelly and Plant, 1981) and homoserine dehydrogenase (Datta et al., 1964).

The complete thermodynamic and kinetic characterisation of an associating-dissociating system requires the use of a number of sophisticated techniques like sedimentation, light scattering, fluorescence polarization etc. (Freiden, 1971). However, the kinetic properties of an associating-dissociating system depends on protein concentration, as an alteration in protein concentration affects the distribution of various $M_{r}$ species in equilibrium (Frieden, 1981). Hence, simple kinetic measurements can be used with reasonable success to gain a qualitative understanding of such systems.

The purified enzyme was exposed to carbamyl phosphate which was demonstrated to alter the equilibrium between the different molecular forms of the enzyme. In order to establish that such inter convertions may have a regulatory significance, it was necessary to use a preparation which was not exposed to carbamyl phosphate and hence second ammonium sulphate fraction free from contaminating activities was used.

The partially purified enzyme showed a decrease in specific activity with increasing protein concentration suggesting that the aggregated forms were less active. Since UMP also caused aggregation to higher $M_{r}$ forms, the observed inhibition by UMP can be explained on the basis of the lower catalytic activity of the aggregated forms.

The complex substrate and allosteric effector saturation plots with maxima and plateau regions observed in some regulatory enzymes were the subject of two theoretical studies (Tiepel and Koshland, 1969; Kurganov et al., 1976; Kurganov, 1977). Tiepel and Koshland (1969) showed that an enzyme exhibiting mixed co-operativity with negative co-operativity followed by positive co-operativity, gave bumpy saturation curves. Kurganov et al. (1976) showed that a hysteretic associating-dissociating enzyme could also produce such complex substrate and allosteric effector saturation 
patterns. Since the complex substrate and allosteric effector saturation plots in mung bean aspartate transcarbamylase disappeared depending on the conditions of preincubation (figures 7,8), a hysteretic mechanism was more probable than a mechanism involving site-site interactions. Such complex saturation curves were observed for some enzymes like E. coli biosynthetic L-threonine dehydratase (Hatfield, 1971; Calhoun et al., 1973; Kagan et al., 1975) and erythrocyte pyruvate kinase (Boivin et al., 1972) which were shown to exhibit a slow association-dissociation of the phenomena (Kagan et al., 1975). The similarities in the properties of mung bean aspartate transcarbamylase and theonine dehydratase permit the postulation of slow association-dissociation phenomenon in the regulation of mung bean enzyme.

\section{Acknowledgements}

The authors wish to thank Dr. H. S. Savithri for helpful discussion. The financial assistance of the University Grants Commission, New Delhi is greatly acknowledged.

\section{References}

Achar, B. S., Savithri, H. S., Vaidyanathan, C. S. and Appaji Rao, N. (1974) Eur. J. Biochem., 47, 15. Adler, S. P., Purich, D. and Stadtman, E. R. (1975) J. Biol. Chem., 250, 6264.

Bethel, M. R. and Jones, M. E. (1969) Arch. Biochem. Biophys., 134, 252.

Boivin, P., Galand, C. and De Martial., M. C. (1972) Pathol. Biol., 20, 583. Chem. Abst., 77, 1490742.

Barbson, J. S. and Switzer, R. L. (1975) J. Biol. Chem., 250, 8664.

Calhoun, D. H., Rimerman, R. A. and Hatfield, G. W. (1973) J. Biol. Chem., 248, 3511.

Collins, K. D. and Stark, G. R. (1971) J. Biol. Chem., 246, 6599.

Datta, P., Gest, H. and Segal., H. L. (1964) Proc. Natl. Acad. Sci. USA, 51, 125.

Davis, B. J. (1964) Ann. N. Y. Acad. Sci., 121, 404.

Feldberg, R. S. and Datta, S. P. (1971) Eur. J. Biochem., 21, 438.

Freiden, C. (1971) Ann. Rev. Biochem., 40, 653.

Freiden, G (1979) Ann. Rev. Biochem., 48, 471.

Freiden, C. (1981) in Protein-Protein interactions, eds. Freiden, C. and Nichol, L. W., (New York: John Wiley and Sons) p. 289.

Gerhart, J. C. and Pardee, A. B. (1962) J. Biol. Chem., 237, 891.

Graf, E., Verma, A. K., Gorski, J. P., Lopaschuk, G., Niggli, V., Zurini, M., Calafoli, E. and Penniston, J. T. (1982) Biochemistry, 21, 4511.

Grayson, J. E. and Yon, R. J. (1978) Biochem. Soc. Trans., 6, 197.

Hatfield, G. W. (1971) Biochem. Biophys. Res. Commun., 44, 464.

Kagan, Z. S., Dorozkko, A. I, Kovaleva, S. V. and Yakovelera, L. I. (1975) Biochim. Biophys. Acta., 403, 208.

Kelley, J. H. and Plant, G. W. E. (1981) J. Biol. Chem., 256, 330.

Koistinen, V. U. (1980) J. Virol., 35, 20.

Kurganov, B. I. (1977) J. Theor. Biol., 68, 521.

Kurganov, B. I., Dorozkko, A. I., Kagan, Z. S. and Yakovlev, V. A. (1976) J. Theor. Biol., 60, 247, $271,287$.

Lowry, O. H., Rosenbrough, N. J., Farr, A. L. and Randall, R. J. (1951) J. Biol. Chem., 193, 265.

Maddy, A. H. (1976) J. Theor. Biol., 62, 315.

Mann, K. G. and Fish, W. W. (1972) Methods Enzymol., 26, 28.

March, C. S., Parikh, I. and Cuatrecasas, P. (1974) Anal. Biochem., 60, 149.

Neumann, J. and Jones, M. E. (1964) Arch. Biochem. Biophys., 104, 438.

Ong, B. L. and Jackson, J. F. (1972) Biochem. J., 129, 571.

Prescott, L. M. and Jones, M. E. (1969) Anal. Biochem., 32, 408.

Rao, G. S. J., Savithri, H. S., Seethalakshmi, S. and Appaji Rao, N. (1979) Annal. Biochem., 95, 401. 
Rao, G. S. J., Prasad, P. V. and Appaji Rao, N. (1982) Biochem. International., 4, 503.

Reddy, A. R. V., Sobhanaditya, J. and Appaji Rao, N. (1980) J. Indian Inst. Sci., 62, 39.

Savithri, H. S., Vaidyanathan, C. S. and Appaji Rao, N. (1978a) Proc. Indian Acad. Sci., 87B, 67.

Savithri, H. S., Vaidyanathan, C. S. and Appaji Rao, N. (1978b) Proc. Indian Acad. Sci., 87B, 81.

Shaltiel, S. and Er-El, Z. (1973) Proc. Natl. Acad. Sci. USA, 70, 778.

Teipel, J. and Koshland, D. E. Jr. (1969) Biochemistry, 8, 4656.

Vickers, L. P. (1981) Trends. Biochem. Sci., 6, 11.

Weber, K. (1968) Nature (London), 218, 1116.

Yon, R. J. (1981) Anal. Biochem., 113, 219.

Yon, R. J., Grayson, J. E., Chawda, A. and Butterworth, P. J. (1982) Biochem. J., 203, 413. 